\title{
Degradation of 2-methylaniline and chlorinated isomers of 2-methylaniline by Rhodococcus rhodochrous strain CTM
}

\author{
Klaus Fuchs, $\dagger$ ANGelika Schreiner and Franz Lingens* \\ Institut für Mikrobiologie, Universität Hohenheim, Garbenstraße 30, D-7000 Stuttgart 70, FRG
}

(Received 31 December 1990; revised 2 April 1991; accepted 13 May 1991)

\begin{abstract}
Rhodococcus rhodochrous strain CTM co-metabolized 2-methylaniline and some of its chlorinated isomers in the presence of ethanol as additional carbon source. Degradation of 2-methylaniline proceeded via 3-methylcatechol, which was metabolized mainly by meta-cleavage. In the case of 3-chloro-2-methylaniline, however, only a small proportion (about $10 \%$ ) was subjected to meta-cleavage; the chlorinated meta-cleavage product was accumulated in the culture fluid as a dead-end metabolite. In contrast, 4-chloro-2-methylaniline was degraded via orthocleavage exclusively. Enzyme assays showed the presence of catechol 1,2-dioxygenase and catechol 2,3dioxygenase as inducible enzymes in strain CTM. Extended cultivation of strain CTM with 2-methylaniline and 3chloro-2-methylaniline yielded mutants, including $R$. rhodochrous strain CTM2, that had lost catechol 2,3dioxygenase activity; these mutants degraded the aromatic amines exclusively via the ortho-cleavage pathway. DNA hybridization experiments using a gene probe revealed the loss of the catechol 2,3-dioxygenase gene from strain CTM2.
\end{abstract}

\section{Introduction}

Because of their high lipophilic character and their ability to interact with DNA (Gorrod \& Manson, 1986; Parris, 1980) anilines containing a methyl- and a chlorosubstituent are hazardous compounds. Therefore investigations on their microbial degradation are of special interest. Some bacterial strains that degrade methylanilines completely have been described (Appel et al., 1984; Raabe et al., 1984; McClure \& Venables, 1986). The presence of a chlorosubstituent on the aromatic ring, however, often causes problems in the microbial degradation of these compounds (Corke et al., 1979; Iwan et al., 1976; Parris, 1980; Surovtseva \& Volnova, 1981). In most of these cases degradation stopped after formation of chlorocatechols or chlorolactones.

In this paper we present data on the metabolism of 2methylaniline and some of its chlorinated isomers by Rhodococcus rhodochrous. To our knowledge this is the first report on the metabolism of chlorinated methylanilines in micro-organisms.

$\dagger$ Present address: Kronwald Separationstechnik, 6920 Sinsheim, FRG.

Abbreviations: C23O, catechol 2,3-dioxygenase; C12O; catechol 1,2dioxygenase.

\section{Methods}

Chemicals. 2-Methylaniline, 3-chloro- and 4-chloro-2-methylaniline were from Riedel de Haen. Methylcatechols were purchased from EGA Chemie. 5-Chloro-3-methylcatechol was synthesized according to Gaunt \& Evans (1971). 3-Chloro- and 4-chlorocatechol, as well as 3,5-dichloro-and 3,6-dichlorocatechol were a generous gift of Professor Dr W. Reineke (Gesamthochschule Wuppertal, FRG).

Isolation and growth of bacteria. Rhodococcus rhodochrous strain CTM was isolated from garden soil with 2-methylaniline as sole carbon source. During extended cultivation of strain CTM with 2-methylaniline a stable mutant, strain CTM2, could be isolated. CTM2 no longer coloured the medium greenish-yellow during the degradation of 2-methylaniline. Cells were grown at $28^{\circ} \mathrm{C}$ at 130 r.p.m. on a rotary shaker. The medium used was as described by Dorn \& Knackmuss $(1978 b)$ with the following modification: instead of $10 \mathrm{mg}$ ferric ammonium citrate $1^{-1}, 8 \mathrm{mg}$ ferrous ammonium sulphate $1^{-1}$ was added. The medium was supplemented with $1 \mathrm{ml}^{-1}$ of a trace element solution according to Pfennig \& Lippert (1966). Aromatic amines were added as a $0.2 \%(\mathrm{v} / \mathrm{v})$ ethanolic stock solution. For experiments with resting cells, bacteria were grown in minimal medium supplemented with $0.5 \%(w / v)$ sorbitol. After $2 \mathrm{~d}$ the washed cell pellet was resuspended in fresh medium (1/10th the original culture volume) containing $1 \mathrm{mM}$ of the appropriate aromatic amine. The methods for large-scale growth of induced biomass and preparation of crude extracts are described in the following paper by Schreiner et al. (1991).

Analytical methods. Degradation products were detected by TLC using toluene/dioxane/acetic acid (72:16:1.6, by vol.) as solvent system. Degradation products were extracted with ethyl acetate from the culture supernatant previously acidified to $\mathrm{pH} 2$ using $\mathrm{H}_{3} \mathrm{PO}_{4}$. For 
isolation of meta-cleavage products, the concentrated ethyl acetate layer was passed through an Adsorbex RP 18 column in order to retain catechol compounds. Compounds separated by preparative TLC were scraped from the silica gel plate and extracted with ethyl acetate or diethyl ether.

The metabolites were identified by coupled gas chromatography/ mass spectrometry (GC, Packard model 427 with flame ionization detector and SE30 fused silica capillary column; MS, Varian MAT 311, $70 \mathrm{eV}$ ). The oven temperature was raised continuously from $80-200^{\circ} \mathrm{C}$ at a rate of $10^{\circ} \mathrm{C} \mathrm{min}^{-1}$. Helium was the carrier gas. Hydroxylated and carboxylated compounds were derivatized using diazomethane.

Liberation of $\mathrm{Cl}^{-}$was assayed with a Marius 'Chlor-o-counter', previously calibrated with $\mathrm{NaCl}$. For qualitative identification of halogen substituents on TLC plates $\mathrm{AgNO}_{3} / \mathrm{H}_{2} \mathrm{O}_{2}$ reagent (Stahl, 1967) and the Beilstein test (Organikum, 1977) were used. The iodoform test was used to detect the presence of the $\mathrm{CH}_{3}-\mathrm{CO}$ group (Organikum, 1977). Catechol compounds were assayed as described by Raabe $e t$ al. (1984). Spraying reagents were prepared as described by Stahl (1967).

Enzyme assays. Catechol 2,3-dioxygenase (C230) activity was assayed as described by Schreiner et al. (1991). Catechol 1,2dioxygenase $(\mathrm{C12O})$ activity was assayed in $20 \mathrm{~mm}$-potassium phosphate buffer, $\mathrm{pH} 7.5$, by monitoring the formation of muconates. The reaction mixture (final vol. $1 \mathrm{ml}$ ) contained an appropriate amount of protein and $300 \mu \mathrm{mol}$ of substrate. Extinction coefficients for muconates were those described by Dorn \& Knackmuss (1978a). When C23O and $\mathrm{C12O}$ - which both converted methylcatechols - were present together in an extract, the activity of either enzyme could be determined by taking advantage of the fact that $\mathrm{C} 23 \mathrm{O}$ is totally inhibited in the presence of $0.2 \mathrm{~mm}-\mathrm{Fe}^{3+}$. One unit (U) of enzyme $(\mathrm{C} 12 \mathrm{O}$ or $\mathrm{C23O})$ is defined as the amount of enzyme converting $1 \mu \mathrm{mol}$ substrate $\min ^{-1}$.

Protein concentration was measured according to Bradford (1976). The presence of the $\beta$-ketoadipate pathway was demonstrated qualitatively by the Rothera reaction (Ottow \& Zolg, 1974). Phenol hydroxylase was assayed according to Straube (1987).

Gel electrophoresis. This was done as described by Schreiner et al. (1991).

Experiments generating the CTM2 phenotype. The influence of aniline derivatives on the loss of $\mathrm{C} 23 \mathrm{O}$ activity was tested as follows. Strain CTM was cultivated at $28^{\circ} \mathrm{C}$ for $5 \mathrm{~d}$ in $25 \mathrm{ml}$ of minimal medium with ethanol $(0.2 \%)$ as carbon source and one of the following aromatic substrates: aniline, $1.0 \mathrm{~mm}$; 3-chloro- and 4-chloro-2-methylaniline, $0.5 \mathrm{~mm}$; 2-methylaniline, $1.0 \mathrm{~mm}$; 4-chloro-2-methylphenol, $0.25 \mathrm{~mm}$; and benzoate, $2.0 \mathrm{~mm}$. At intervals of $5 \mathrm{~d}$ an aliquot $(1 \mathrm{ml})$ from each culture flask was transferred to fresh medium. In this way, strain CTM was cultivated for 10 weeks. Then an aliquot from each flask was plated on minimal agar plates containing sorbitol as carbon source. A total of 500 colonies from every assay were tested on titre plates for metacleavage activity: 24-well Costar plates were used and each well was filled with $1 \mathrm{ml}$ of minimal medium containing $0.5 \mathrm{~mm}$-3-chloro-2methylaniline. The formation of the yellow-green dead-end metabolite 2-hydroxy-5-chloro-6-oxoheptadienoic acid indicated meta-cleavage activity.

Reversion test. Strain CTM2 was cultivated on minimal medium containing either 2-methylaniline or sorbitol. An aliquot from each culture flask was plated on minimal agar plates containing sorbitol. A total of 2000 colonies from each culture were examined for metacleavage activity, as described above.

DNA isolation and hybridization. These were done as described by Schreiner et al. (1991).

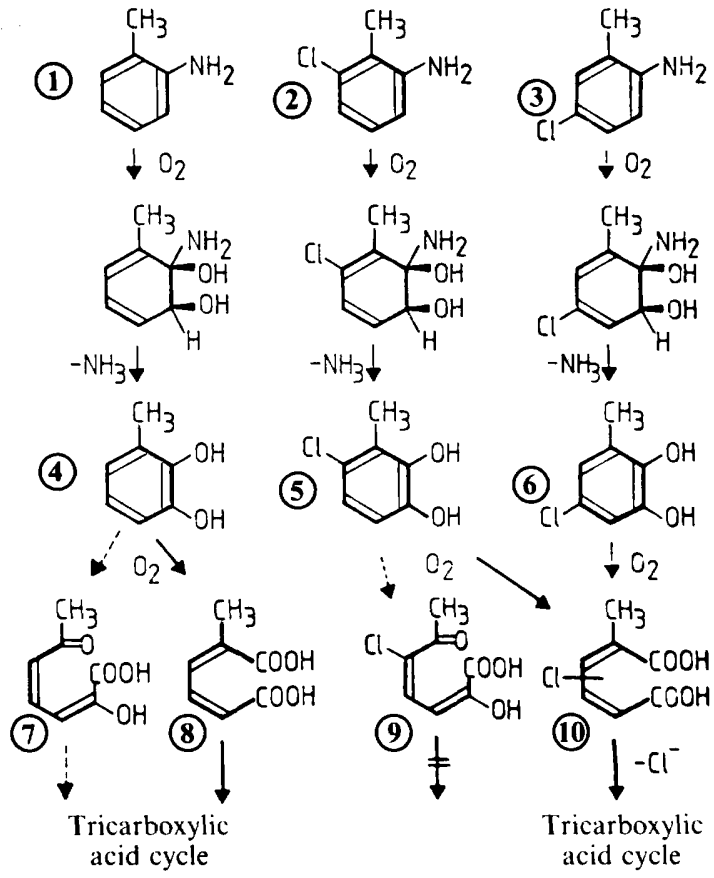

Fig. 1. Proposed pathway for the degradation of 2-methylaniline, 3chloro- and 4-chloro-2-methylaniline by $R$. rhodochrous strains CTM and CTM2. Compounds are as follows: 1, 2-methylaniline; 2, 3-chloro2-methylaniline; 3, 4-chloro-2-methylaniline; 4, 3-methylcatechol ; 5, 4chloro-3-methylcatechol; 6, 5-chloro-3-methylcatechol; 7, 2-hydroxy-6oxoheptadienoic acid; 8, 2-methylmuconic acid; 9, 2-hydroxy-5-chloro6-oxoheptadienoic acid; 10, 3- or 4-chloro-2-methylmuconic acid. Compounds 4 to 9 were identified as degradation products. $\rightarrow$, pathway used by $R$. rhodochrous strains CTM and CTM2; --.degradation steps used by $R$. rhodochrous strain CTM only.

\section{Results}

Growth on methylanilines in the presence and absence of ethanol

$R$. rhodochrous strain CTM was isolated from garden soil with 2-methylaniline (compound 1, Fig. 1) as the elective carbon source. During degradation studies the spontaneous mutant strain CTM2 was detected by its inability to colour the methylaniline growth medium. The mutant strain CTM2 proved stable, no revertants to the phenotype of strain CTM being found. Both strains showed only weak growth on solid and in fluid media containing one of the methylanilines as sole carbon and nitrogen source. Degradation proceeded very slowly and did not exceed $85 \%$ within 3 months. However, the presence of ethanol as additional carbon source led to better growth of the bacteria and to total breakdown of the aromatic amines within 6-8 d. Therefore all degradation studies were done in the presence of ethanol. The optimal substrate concentrations of 2-methylaniline were 
Table 1. Mass spectrometric data of isolated metabolites

\begin{tabular}{|c|c|c|}
\hline Degradation substrate & Isolated compound/identified as & Major fragment ions $(m / z$; percentage relative intensity) \\
\hline 2-Methylaniline & 3-Methylcatechol/3-methylveratrole & $\begin{array}{l}M^{+}(152 ; 100 \%) ; M^{+}-\mathrm{CH}_{3}(137 ; 60 \%) ; M^{+}-\mathrm{COCH}_{3} \\
(109 ; 53 \%) ; \mathrm{C}_{6} \mathrm{H}_{5}^{+}(77 ; 71 \%)\end{array}$ \\
\hline 2-Methylaniline & $\begin{array}{l}\text { 2-Methylmuconic acid/2-methylmuconic } \\
\text { acid dimethylester* }\end{array}$ & $\begin{array}{l}M^{+}(184 ; 0.7 \%) ; M^{+}-\mathrm{CH}_{3}(169 ; 1.4 \%) ; M^{+}-\mathrm{OCH}_{3} \\
(153 ; 2.9 \%) ; M^{+}-\mathrm{COOCH}_{3}(125 ; 100 \%)\end{array}$ \\
\hline 2-Methylaniline & $\begin{array}{l}\text { 2-Hydroxy-6-oxohepta-2,4-dienoic } \\
\text { acid/respective methylester }\end{array}$ & $\begin{array}{l}M^{+}(184 ; 3 \%) ; M^{+}-\mathrm{CH}_{3}(169 ; 3 \%) ; M^{+}-\mathrm{CH}_{3} \mathrm{CO}(141 ; 18 \%) ; \\
M^{+}-\mathrm{COOCH}_{3}(125 ; 100 \%) ; M^{+}-\mathrm{CH}_{3} \mathrm{CO},-\mathrm{COOCH}_{3} \\
(82 ; 13 \%)\end{array}$ \\
\hline 3-Chloro-2-methylaniline & $\begin{array}{l}\text { 4-Chloro-3-methyl-catechol/4-chloro-3- } \\
\text { methylveratrole }\end{array}$ & $\begin{array}{l}M^{+}(186+; 92 \%) ; M^{+}-\mathrm{CH}_{3}(171 \dagger ; 69 \%) ; M^{+}-\mathrm{CH}_{3} \mathrm{CO},-\mathrm{Cl} \\
(108 ; 100 \%) ; \mathrm{C}_{6} \mathrm{H}_{5}^{+}(77 ; 75 \%)\end{array}$ \\
\hline 3-Chloro-2-methylaniline & $\begin{array}{l}\text { 2-Hydroxy-5-chloro-6-oxoheptadienoic } \\
\text { acid/respective methylester }\end{array}$ & $\begin{array}{l}M^{+}(218+; 2 \%) ; M^{+}-\mathrm{CH}_{3} \mathrm{CO}(175 \dagger ; 4 \%) ; M^{+}-\mathrm{COOCH}_{3} \\
(159+; 100 \%) ; M^{+}-\mathrm{CH}_{3} \mathrm{CO}-\mathrm{CH}_{3} \mathrm{O}(144+; 8 \%) ; \\
M^{+}-\mathrm{COOCH} 3,-\mathrm{Cl}(123 ; 1 \%) ; M^{+}-\mathrm{CH}_{3} \mathrm{CO},-\mathrm{COOCH}_{3} \\
(116+; 10 \%)\end{array}$ \\
\hline 4-Chloro-2-methylaniline & $\begin{array}{l}\text { 4-Chloro-2-methylphenol/4-chloro-2- } \\
\text { methylphenol* }\end{array}$ & $\begin{array}{l}M^{+}(142 \dagger ; 30 \%) ; M^{+}-\mathrm{H}_{2} \mathrm{O}(124 \dagger ; 2 \%) ; M^{+}-\mathrm{Cl}(107 ; 86 \%) \\
\mathrm{C}_{6} \mathrm{H}_{5}+(77 ; 53 \%)\end{array}$ \\
\hline 4-Chloro-2-methylaniline & $\begin{array}{l}\text { 5-Chloro-3-methylcatechol/5-chloro-3- } \\
\text { methylveratrole* }\end{array}$ & $\begin{array}{l}M^{+}(186+; 94 \%) ; M^{+}-\mathrm{CH}_{3}(171 \dagger ; 68 \%) ; M^{+}-\mathrm{OCH}_{3},-\mathrm{OCH}_{3} \\
(125+; 26 \%) ; M^{+}-\mathrm{COCH}_{3},-\mathrm{Cl}(108 ; 100 \%) ; \mathrm{C}_{6} \mathrm{H}_{5}^{+}(77 ; \\
75 \%)\end{array}$ \\
\hline
\end{tabular}

* Authentic compounds available for comparison.

+ With chloro pattern.

$0.5-1.0 \mathrm{mM}$ and $0.1-0.5 \mathrm{~mm}$ for the chloromethylanilines for both strains. Mutant strain CTM2 possessed a slightly higher tolerance to the chloromethylanilines (up to $1.0 \mathrm{mM}$ ), but degradation of the aromatic amines took the same time as in strain CTM.

Degradation of 2-methylaniline and chlorinated isomers in wild-type strain CTM

(i) 2-Methylaniline. The first compound isolated from growth cultures or from cultures of resting cells showed a TLC $R_{F}$ value of 0.48 , identical with the $R_{F}$ value of authentic 3-methylcatechol. Both spots turned orange-red on spraying the thin-layer plate with nitrite/molybdate reagent. In GC/MS the methylated compound yielded a mass spectral fragmentation pattern identical with authentic 3-methylveratrole (Table 1). When 3-methylcatechol was added to crude extracts of cells grown on 2methylaniline it was converted to a greenish-yellow product. During degradation of 2-methylaniline the medium also turned greenish-yellow $38 \mathrm{~h}$ after inoculation and retained this colour for about $12 \mathrm{~h}$; thereafter it became colourless. The yellow compound isolated from the greenish-yellow culture fluid had an absorption maximum at $387 \mathrm{~nm}$ at $\mathrm{pH} 7$ and $\mathrm{pH} 12$. At $\mathrm{pH} 2$ the maximum shifted to $320 \mathrm{~nm}$. These UV data were identical with those described for 2-hydroxy-6-oxoheptadienoic acid (compound 7, Fig. 1) by Catelani et al. (1968). The iodoform test was positive, indicating the presence of the $\mathrm{CH}_{3}-\mathrm{CO}$ group. The methylated substance had a GC retention time of $4.6 \mathrm{~min}$, and mass spectral data could be attributed to 2-hydroxy-6-oxo- hepta-2,4-dienoic acid methylester (Table 1). From the culture supernatant of resting cells of strain CTM 2methylmuconic acid (compound 8, Fig. 1) could be isolated. The methylated metabolite showed a mass spectral fragmentation pattern identical with 2-methylmuconic dimethylester (Table 1), prepared by methylation of authentic 2-methylmuconic acid with diazomethane. 2-Methylmuconic acid was metabolized by crude extracts prepared from 2-methylaniline-induced cells of strain CTM, but not by extracts from uninduced cells.

(ii) 3-Chloro-2-methylaniline. Strain CTM, when grown on a medium containing $1 \mathrm{~mm}$-3-chloro-2-methylaniline, accumulated a brownish compound. Reaction with nitrite/molybdate reagent identified the compound as a catechol derivative and with the Beilstein test the presence of halogen was detected. The chlorocatechol had an $R_{F}$ value of 0.48 on TLC, and the methylated compound had a GC retention time of $6.1 \mathrm{~min}$. The mass spectrum (Table 1) was nearly identical to that of synthesized 5-chloro-3-methylveratrole, which had a different GC retention time $(6.8 \mathrm{~min})$. Therefore, we propose that the compound isolated is identical with the isomer 4-chloro-3-methylcatechol (compound 5, Fig. 1). Crude extracts of cells induced on 3-chloro-2-methylaniline transformed this chloromethylcatechol to a greenish-yellow product. This compound was also found to accumulate in the culture fluid during 3-chloro-2methylaniline degradation. The isolated compound exhibited a UV spectrum with absorption maxima at $390 \mathrm{~nm}(\mathrm{pH} \mathrm{7.5)}$ and $325 \mathrm{~nm}(\mathrm{pH} \mathrm{2.0)}$, shifting back to $390 \mathrm{~nm}$ at $\mathrm{pH} 10$ due to keto-enol tautomerism. These characteristics and the mass spectral data (Table 1) led us 
to postulate that the isolated substance is identical with 2-hydroxy-5-chloro-6-oxoheptadienoic acid (compound 9, Fig. 1).

The amount of chlorinated heptadienoic acid formed was estimated with the aid of the molar absorption coefficient of the structural analogue 2-hydroxy-6oxoheptadienoic acid (compound 7, Fig. 1). During degradation of 3-chloro-2-methylaniline samples were taken from the culture fluid and the amount of metacleavage product was estimated. The meta-cleavage product increased continuously up to $0.05 \mathrm{mM}$ during breakdown of $0.5 \mathrm{~mm}$-3-chloro-2-methylaniline. This amount remained constant during the stationary growth phase, indicating the transformation of about $10 \%$ of the original substrate to a dead-end metabolite, whereas $90 \%$ of the original substrate must have been channelled into the ortho-cleavage pathway. This was confirmed by a $\mathrm{Cl}^{-}$ liberation of about $90 \%$ and a positive Rothera reaction in crude extracts.

(iii) 4-Chloro-2-methylaniline. During degradation of this compound (3, Fig. 1) no meta-cleavage product was detectable in culture fluids; instead two compounds could be isolated from ethyl acetate extracts of culture supernatant. The first compound (GC retention time $5.6 \mathrm{~min}$ ) showed a mass spectrum identical with authentic 4-chloro-2-methylphenol (Table 1); the second $\left(R_{F}\right.$ value 0.56 on TLC; UV maxima at $283 \mathrm{~nm}$ and $213 \mathrm{~nm}$ ) was identified as 5-chloro-3-methylcatechol (compound 6 , Fig. 1). This latter compound (GC retention time 6.6 min) generated a mass spectrum identical with authentic 5-chloro-3-methylveratrole (Table 1). Crude extracts prepared from cells grown on 4-chloro-2methylaniline converted 5-chloro-3-methylcatechol to colourless products. About $96 \%$ of the theoretical amount of $\mathrm{Cl}^{-}$was released. This fact, together with a positive Rothera reaction, suggests degradation of the catechol via the ortho-cleavage pathway. Phenol hydroxylase activity, converting 4-chloro-2-methylphenol to 5-chloro-3-methylcatechol, could not be demonstrated. Therefore we assume that 4-chloro-2-methylphenol is not a degradation product of 4-chloro-2-methylaniline but rather an artefactual product formed by dehydration of the corresponding dihydrodiol during the acid-extraction procedure.

\section{Degradation of 2-methylaniline and chlorinated isomers by mutant strain CTM2}

During degradation of 2-methylaniline, 3-chloro- and 4chloro-2-methylaniline the culture fluid did not become greenish-yellow. Crude extracts obtained from each culture converted the corresponding catechols to colourless products which gave a positive Rothera reaction. In the case of 3-chloro-2-methylaniline $96.5 \%$ and in the case of 4-chloro-2-methylaniline $96 \%$ of the theoretical amount of $\mathrm{Cl}^{-}$was released during degradation, suggesting breakdown exclusively via ortho-cleavage. From cultures of resting cells, induced with 2-methylaniline, 2methylmuconic acid (compound 8, Fig. 1) could be isolated and identified. From culture fluids of cells grown on 4-chloro-2-methylaniline, 5-chloro-3-methylcatechol (compound 6, Fig. 1) was isolated and identified.

\section{Induction of catechol dioxygenases in strains CTM and CTM2}

Crude extracts of cells grown in the presence and absence of aromatic amines were assayed for meta- and orthocleaving dioxygenases (Table 2). Dioxygenase activity was only detectable in crude extracts of cells grown in the presence of aromatic amines. $\mathrm{C} 23 \mathrm{O}$, the meta-cleaving enzyme was not detectable in strain CTM2.

\section{Substrate range of the $C 120$ of mutant strain CTM2}

Cells of strain CTM2 grown on 4-chloro-2-methylaniline yielded crude extracts which converted the following catechols (relative activity in \%): catechol $(100 \%)$; 3chlorocatechol $(155 \%) ;$ 4-chlorocatechol $(32 \%)$; 3methylcatechol $(36 \%)$; 4-methylcatechol $(18 \%)$; 5chloro-3-methylcatechol $(159 \%) ; 3,5$-dichlorocatechol $(86 \%)$; 3,6-dichlorocatechol $(150 \%)$; tetrachlorocatechol $(0 \%)$. [100\% was $0.7 \mathrm{mU}$ (mg crude extract) ${ }^{-1}$.] A positive Rothera reaction, evidence for the presence of end products of the ortho-cleavage pathway, indicated an intact degradative sequence after muconic acid derivatives.

\section{Experiments generating the CTM2 phenotype}

Repeated transfers of cells of strain CTM grown on aromatic amines gave rise to cells of the CTM2 phenotype. Especially with 2-methylaniline and with 3chloro-2-methylaniline as growth substrates, a nearly complete loss of the meta-cleaving enzyme, as shown by a colourless test medium, was observed after ten transfers (Table 3).

\section{Genetics of spontaneous $\mathrm{C}^{23 \mathrm{O}^{-}}$mutants}

From the culture with 2-methylaniline, we selected one mutant (strain CTM2) to investigate the genetic background of the $\mathrm{C}^{2} 3 \mathrm{O}^{-}$phenotype.

$R$. rhodochrous was found to harbour two plasmids, pTC1 and pTC2 (see following paper; Schreiner et al., 1991). Plasmid DNA and total DNA from the wild-type 
Table 2. Induction of catechol dioxygenases tested with 3-methylcatechol as substrate in $R$. rhodochrous strains CTM and CTM2

Specific activities of the meta-cleaving enzyme $\mathrm{C} 23 \mathrm{O}$ and the ortho-cleaving enzyme C12O in crude extracts of strains CTM and CTM2 grown on different media are shown. Enzymes are assayed as described in Methods; activities are given in mU (mg crude extract protein $)^{-1}$.

\begin{tabular}{|c|c|c|c|c|}
\hline \multirow[b]{2}{*}{ Growth medium } & \multicolumn{2}{|c|}{ Strain CTM } & \multicolumn{2}{|c|}{ Strain CTM2 } \\
\hline & $\mathrm{C} 23 \mathrm{O}$ & $\mathrm{C} 12 \mathrm{O}$ & $\mathrm{C} 230$ & $\mathrm{C} 12 \mathrm{O}$ \\
\hline 2-Methylaniline + ethanol & $12 \cdot 5$ & 0.55 & 0 & 1.7 \\
\hline 3-Chloro-2-methylaniline + ethanol & $6 \cdot 07$ & 0.77 & $\mathbf{0}$ & $2 \cdot 1$ \\
\hline 4-Chloro-2-methylaniline + ethanol & $6 \cdot 4$ & 0.6 & $\mathbf{0}$ & 1.0 \\
\hline Ethanol & 0 & 0 & 0 & 0 \\
\hline Nutrient broth & 0 & 0 & 0 & 0 \\
\hline
\end{tabular}

Table 3. Effect of different aromatic amines on the loss of meta-cleavage activity

From each transfer 500 colonies $(=100 \%$ ) were tested as described in Methods. UV spectra of the yellow media showed maxima at $390 \mathrm{~nm}$ (pH 7.5) and $325 \mathrm{~nm}(\mathrm{pH} \mathrm{2.0)}$, identical with the UV data of 2-hydroxy-5-chloro-6-oxoheptadienoic acid.

\begin{tabular}{|c|c|c|c|c|c|c|}
\hline \multirow{2}{*}{\multicolumn{2}{|c|}{ Growth medium }} & \multicolumn{2}{|c|}{ 1st transfer } & \multicolumn{3}{|c|}{ 10th transfer } \\
\hline & & \multicolumn{2}{|c|}{$\%$ Yellow-green $\%$, Colourless $\left(\mathrm{C}^{23 \mathrm{O}^{-}}\right)$} & \multirow{2}{*}{$\frac{\% \text { Yellow-green } \%}{29}$} & \multirow{2}{*}{$\frac{\text { Colourless } \%}{11}$} & \multirow{2}{*}{$\frac{\text { Brownish }^{*}}{60}$} \\
\hline Aniline & \multirow{8}{*}{+ Ethanol } & 100 & 0 & & & \\
\hline 2-Methylaniline & & 99.6 & $0 \cdot 4$ & $4 \cdot 2$ & 95.8 & 0 \\
\hline 3-Chloro-2-methylaniline & & 100 & 0 & 0 & 100 & 0 \\
\hline 4-Chloro-2-methylaniline & & 100 & 0 & $93 \cdot 8$ & $6 \cdot 2$ & 0 \\
\hline 5-Chloro-2-methylaniline & & 100 & $\mathbf{0}$ & $94 \cdot 2$ & $5 \cdot 8$ & 0 \\
\hline 4-Chloro-2-methylphenol & & 100 & 0 & $99 \cdot 2$ & 0.8 & 0 \\
\hline Benzoate & & $99 \cdot 6$ & 0.4 & 99.8 & 0.2 & 0 \\
\hline Ethanol & & 100 & $\mathbf{0}$ & 99.8 & $0 \cdot 2$ & 0 \\
\hline
\end{tabular}

* Brownish colourization of the medium occurred due to the autoxidation of accumulated 4-chloro-3-methylcatechol.

strain CTM and the mutant strain CTM2 were isolated. Restriction enzyme analysis revealed the deletion of a continuous DNA region of about $27 \mathrm{~kb}$ in plasmid pTCl. After digestion of plasmid and total DNA with $B g I I I$ and size fractionation by gel electrophoresis, the blotted DNA was probed with a radiolabelled oligonucleotide obtained from the sequence of C23OI. A strong signal was obtained from a $3.5 \mathrm{~kb}$ fragment of the plasmid DNA and total DNA of strain CTM, but plasmid DNA and total DNA from the mutant strain CTM2 gave no signal on the autoradiogram. Restriction enzyme analysis showed that the same $3.5 \mathrm{~kb} B g / \mathrm{II}$ restriction fragment was absent. Therefore, we conclude that the C23OI gene is completely lost in mutant strain CTM2. On the same restriction fragment a second catechol 2,3dioxygenase (C23OII) was found during cloning experiments (Schreiner et al., 1991). Obviously, the C23OII gene was lost in mutant strain CTM2, too. To find out whether mutants selected by repeated transfer on various methylanilines (see above) had lost only one specific part of the plasmid, we isolated plasmid DNA from a further
30 randomly chosen colonies. Restriction enzyme analysis and probing of $B g l \mathrm{II}$-restricted DNA with the radiolabelled oligonucleotide showed that the genetic material of colonies devoid of $\mathrm{C23OI}$ activity possessed deletions in the $3.5 \mathrm{~kb} \mathrm{BglII}$ restriction fragment and additionally in other plasmid DNA regions. Unspecific deletions in the plasmid DNA, however, were also observed in colonies which still expressed C23OI activity. Obviously, cultivation on methylanilines caused an unspecific loss of DNA regions.

\section{Discussion}

The wild-type strain $R$. rhodochrous CTM, as well as its mutant strain CTM2, was able to grow with 2methylaniline, 3-chloro- and 4-chloro-2-methylaniline as sole sources of carbon and nitrogen.

Weak growth on solid and in liquid media, however, suggested difficulties in the metabolism of these compounds. This was probably due to an insufficient amount 
of energy or reduced cofactors for the initial dioxygenase reaction, as stated by D. Janke and co-workers (Janke \& Fritsche, 1985; Janke et al., 1988) when discussing chloroaniline co-metabolism by Rhodococcus AN117.

The degradation of the methylanilines proceeded via the corresponding catechols in both $R$. rhodochrous strains, suggesting a common degradative base branch, including oxidative deamination as described for aniline metabolism by Nocardia (Bachofer \& Lingens, 1983). 2-Methylaniline was metabolized mainly by metacleavage, whereas a positive Rothera reaction together with a nearly quantitative release of $\mathrm{Cl}^{-}$during 3-chloroand 4-chloro-2-methylaniline degradation indicated the presence of an active ortho-cleavage pathway in strain CTM. Therefore we propose a degradation pathway for the chloromethylanilines similar to that described for the metabolism of 4-chloro-2-methylphenoxyacetate and p-chlorotoluene (Gaunt \& Evans, 1971; Haigler \& Spain, 1989).

The difference between the wild-type strain CTM and the mutant CTM2, as described in this paper, lies in the different conversion of 3-methylcatechol. The enzyme C23O catalyses an efficient transformation of 3-methylcatechol in strain CTM, whereas the mutant CTM2 does not possess $\mathrm{C} 23 \mathrm{O}$ activity. The loss of the meta-cleaving enzyme leads to a phenotype with lower degradation capacity towards 2-methylaniline, but - due to the elimination of a misrouting meta-cleavage pathway - to a more efficient degradation of chloromethylcatechols via ortho-cleavage.

Long-duration exposure of $R$. rhodochrous wild-type strain CTM to different aniline derivatives generated cells of the CTM2 phenotype with a high frequency. Two aspects may contribute to this phenomenon. (i) The most effective 'curing agents' were 3-chloro-2-methylaniline, 2-methylaniline and aniline. The spontaneous mutation rate of $0.2 \%$ indicated that all aromatic amines had a high 'curing' potential (Table 3 ). These compounds may affect the stability of plasmid pTC1 perhaps by causing unspecific deletions of DNA regions, resulting in the $\mathrm{C}^{23 \mathrm{O}^{-}}$phenotype. From studies with eukaryotic DNA it is known that $N$-hydroxylation of aromatic amines leads to reactive compounds which can interact with DNA (Gorrod \& Manson, 1986; Parris, 1980). A direct influence of a growth substrate on 'curing' of catabolic genes was proposed by Stephens \& Dalton $(1987,1988)$ in the case of 'benzoate-curing' of catabolic genes from TOL plasmids. The authors assumed that benzoate directly influenced the stability of TOL plasmids. Perhaps aromatic amines or their reactive derivatives also directly influence the DNA in $R$. rhodochrous. (ii) Cells that have lost the $\mathrm{C} 23 \mathrm{O}$ gene(s) may acquire a growth advantage, as described by Williams et al. (1988) for 'benzoate-cured' segregants.
Perhaps both aspects play a role in the 'curing' event exerted by the growth substrate.

This work was supported by the Bundesministerium für Forschung und Technologie and the Fonds der Chemischen Industrie.

We are obliged to Dr J. Eberspächer for critical reading of the manuscript and to Mr K. Kapassakalis for conscientious performance of fermentations.

\section{References}

APPEL, M., RAABE, T. \& Lingens, F. (1984). Degradation of $o$-toluidine by Rhodococcus rhodochrous (Sb4). FEMS Microbiology Letters 24, 123-126.

BACHOFER, R. \& LINGENS, F. (1983). Degradation of carboxanilide fungicides by a Nocardia spec. Hoppe-Seyler's Zeitschrift für Physiologische Chemie 364, 21-29.

BRADFORD, M. M. (1976). A rapid and sensitive method for the quantitation of microgram quantities of protein utilizing the principle of protein-dye binding. Analytical Biochemistry 72, 248254.

Catelani, D., Fiecchi, A. \& Galli, E. (1968). Formation of 2hydroxy-6-oxo-2,trans-4,trans-heptadienoic acid from 3-methylcatechol by a Pseudomonas. Experientia 24, 113.

Corke, Ch. T., Bunce, N. J., Beaumont, A. L. \& Merrick, R. L. (1979). Diazonium cations as intermediates in the microbial transformation of chloroanilines to chlorinated biphenyls, azocompounds and triazenes. Journal of Agricultural and Food Chemistry 27, 644-646.

DoRn, E. \& KNACKmuss, H.-J. (1978a). Chemical structure and biodegradability of halogenated aromatic compounds. Two catechol 1,2-dioxygenases from a 3-chlorobenzoate grown pseudomonad. Biochemical Journal 174, 73-84.

DoRn, E. \& KNACKmuss, H.-J. (1978b). Chemical structure and biodegradability of halogenated aromatic compounds. Substituent effects on 1,2-dioxygenation of catechol. Biochemical Journal 174, 85-94.

Gaunt, J. K. \& Evans, W. C. (1971). Metabolism of 4-chloro-2methylphenoxyacetate by a soil pseudomonad. Biochemical Journal 122, 519-526.

GoRrod, J. W. \& MANSON, D. (1986). The metabolism of aromatic amines. Xenobiotica 16, 933-955.

HAIGLER, B. E. \& Spain, J. C. (1989). Degradation of $p$-chlorotoluene by a mutant of Pseudomonas sp. strain JS6. Applied and Environmental Microbiology 55, 372-379.

Iwan, J., Hoyer, G. H., Rosenberg, D. \& Goller, D. (1976). Transformation of 4-chloro-o-toluidine in soil: generation of coupling products by one electron oxidation. Pesticide Science 7, 621-631.

JANKE, D. \& FRITSCHE, W. (1985). Nature and significance of microbial cometabolism of xenobiotics. Journal of Basic Microbiology 25, 603-619.

Janke, D., Al-Mofarj, T., Straube, G., Schumann, P. \& Prauser, H. (1988). Critical steps in degradation of chloroaromatics by rhodococci. Journal of Basic Microbiology 28, 509-528.

MCClure, N. C. \& Venables, W. A. (1986). Adaption of Pseudomonas putida mt-2 to growth on aromatic amines. Journal of General Microbiology 132, 2209-2218.

ORGANIKUM (1977). Berlin: VEB Deutscher Verlag der Wissenschaften.

OtTow, J. C. G. \& ZolG, W. (1974). Improved procedure and colourimetric test for the detection of ortho- and meta-cleavage of protocatechuate by Pseudomonas isolates. Canadian Journal of Microbiology 20, 1059-1061.

PARRIS, G. E. (1980). Environmental and metabolic transformations of primary aromatic amines and related compounds. Residue Reviews 76, 2-24.

PfenNig, N. \& Lippert, K. D. (1966). Über das Vit. B ${ }_{12}$ Bedürfnis phototropher Schwefelbakterien. Archiv für Mikrobiologie 55, 245256. 
RAABe, T., APPEL, M. \& Lingens, F. (1984). Degradation of $p$-toluidine by Pseudomonas testosteroni. FEMS Microbiology Letters 25, 61-64. Schreiner, A., Fuchs, K., LotTspeich, F., Poth, H. \& Lingens, F. (1991). Degradation of 2-methylaniline in Rhodococcus rhodochrous: cloning and expression of two clustered catechol 2,3-dioxygenase genes from strain CTM. Journal of General Microbiology 137, 20412048.

StaHL, E. (editor) (1967). Dünnschichtchromatographie. Berlin: Springer Verlag.

StePhens, G. M. \& Dalton, H. (1987). The effect of lipophilic weak acids on the segregational stability of TOL plasmids in Pseudomonas putida. Journal of General Microbiology 133, 1891-1899.

StePhENS, G. M. \& Dalton, H. (1988). Kinetics of benzoate-induced loss of the TOL plasmid from Pseudomonas putida MT15 during growth in chemostat culture. FEMS Microbiology Letters 55, 175180.

Straube, G. (1987). Phenolhydroxylase from Rhodococcus sp. P1. Journal of Basic Microbiology 27, 229-232.

Surovtseva, E. G. \& Volnova, A. J. (1981). 4-Chlorocatechol, an inhibitor of pyrocatechol 2,3-dioxygenase in Alcaligenes faecalis. Mikrobiologiya 50, 386-388.

Williams, P. A., TaYlor, S. D. \& GibB, L. E. (1988). Loss of the toluene-xylene catabolic genes of TOL plasmid pWW0 during growth of Pseudomonas putida on benzoate is due to a selective growth advantage of 'cured' segregants. Journal of General Microbiology 134, 2039-2048. 